Article

\title{
The Relationship between the Integration of CSR and Sustainable Business Performance: Perceptions of SMEs in the South African Construction Industry
}

\author{
Lance Wentzel $^{1, *}$, Julius Ayodeji Fapohunda ${ }^{2}$ and Rainer Haldenwang ${ }^{1}$ \\ 1 Department of Civil Engineering and Surveying, Cape Peninsula University of Technology, \\ Bellville 7530, South Africa; haldenwangr@cput.ac.za \\ 2 Department of Construction Management and Quantity Surveying, Cape Peninsula University of Technology, \\ Bellville 7530, South Africa; fapohundaj@cput.ac.za \\ * Correspondence: wentzell@cput.ac.za; Tel.: +27-21-959-6630
}

Citation: Wentzel, L.; Fapohunda, J.A.; Haldenwang, R. The

Relationship between the Integration of CSR and Sustainable Business Performance: Perceptions of SMEs in the South African Construction Industry. Sustainability 2022, 14, 1049. https://doi.org/10.3390/su14031049

Academic Editors: Mark Anthony Camilleri, Andrea Pérez,

Valentín Molina-Moreno and Juan

Victor Meseguer Sánchez

Received: 27 September 2021

Accepted: 22 December 2021

Published: 18 January 2022

Publisher's Note: MDPI stays neutral with regard to jurisdictional claims in published maps and institutional affiliations.

Copyright: (c) 2022 by the authors. Licensee MDPI, Basel, Switzerland. This article is an open access article distributed under the terms and conditions of the Creative Commons Attribution (CC BY) license (https:// creativecommons.org/licenses/by/ $4.0 /)$.

\begin{abstract}
Although studies relative to redirecting the unsustainable trajectory of small and medium enterprises (SMEs) in the South African construction industry (SACI) have been extensively conducted, current statistics show that $70-80 \%$ of construction SMEs in the SACI fail within their first five years of existence, raising concerns regarding their sustainability. This paper attempts to address the negative trajectory by exploring the concept of corporate social responsibility (CSR), investigating the organisational perceptions of SMEs in the SACI relative to the relationship between the integration of CSR and sustainable business performance (SBP). Existing literature was used to provide an overview of this relationship taking into consideration the views of SMEs in both developed and developing countries. The empirical study was conducted utilising a quantitative research approach in the form of an online questionnaire survey. The research data was analysed using both descriptive (mean, standard deviation, etc.) and inferential (Analysis of Variance ANOVA) statistics. Based on the research approach and data analysis, the findings revealed that SMEs in the SACI similarly perceive the relationship between the integration of CSR and SBP to be a positive one, implying that the practice of CSR within construction businesses should lead to SBP, and serve as a meaningful guide in addressing the unsustainable trajectory of SMEs in the SACI. The findings could guide government agencies such as the construction industry development board (cidb) to embed CSR education within contractor development programs, linking the adoption of CSR to the contractor grading system.
\end{abstract}

Keywords: corporate social responsibility; perceptions; South Africa; sustainable business performance

\section{Introduction}

Although SMEs in South Africa employ $47 \%$ of the workforce, contribute to more than $20 \%$ of GDP and pay approximately $6 \%$ of all corporate taxes, many show signs of unsustainable business performance in their first year of existence [1]. It is the view of [2] that $70-80 \%$ of SMEs in South Africa do not manage to survive one year of business existence. These signs of unsustainable business performance are not only for SMEs in general, but also reflect negatively on construction SMEs, where $70-80 \%$ of fail within their first five years of existence. This raises huge concerns with regard to the sustainability of construction SMEs in South Africa.

To address this problem various authors such as [3-8], have all conducted research on SMEs in the SACI and have highlighted factors threatening the SBP and survival of SMEs relative to the lack of: SME owner managers' management knowledge (planning capacity, resourcing, leadership and controlling capacity); business knowledge and self-knowledge; industry experience in the chosen area of business such as construction; business acumen, aptitude, and entrepreneurial mind-set to form and raise a successful enterprise. However, these studies have not considered the notion of CSR and its link to stakeholder theory 
as a driver to the SBP of SMEs in the SACI, which is supported by $[9,10]$ suggesting that business performance is purely measured by the way a business satisfies its stakeholders, thus motivating this study to explore the concept of corporate social responsibility (CSR), investigating the organisational perceptions of SMEs in the SACI relative to the relationship between the integration of CSR and sustainable business performance (SBP).

According to [11] there has been extensive practical and academic interest in CSR and its impact on the SBP of SME businesses in general. Theoretical and empirical studies are, however, limited and studies such as the ones conducted by [11-18] have placed extensive focus on CSR by general SMEs in developing countries. Similarly, studies conducted by [19-24] have focused on CSR by general SMEs in South Africa. There also seems to be a need to address the theoretical and empirical limitations pertaining to CSR, particularly the use of CSR by SMEs in the SACI.

Although CSR is a widely embraced social phenomenon captured in general business literature it has in recent years begun to attract research interest globally in the construction industry. A study conducted by [25] confirmed that CSR research in the construction industry world-wide is still in its initial stages. They further confirmed, utilising descriptive methods such as frequency, percentage, and the use of figures, across the Scopus academic database, Emerald, Taylor and Francis, Elsevier and Google Scholar, that between the year 2005 and 2017, 68 reliable journal papers were sourced relating to CSR in the construction industry. These journal papers were sourced from 21 countries covering all the continents. From these 21 countries the UK (19) and China (10) had the highest number of papers, followed by Australia (9), the USA (4), South Korea (4) and others ( 2 and below). Themes covered, related to CSR perceptions, CSR dimensions, CSR implementation and CSR performance. In contrast a study conducted by [26] established that between the year 2006 to 2018, 50 journal papers and 19 conference papers were published dealing with the following CSR themes linked to construction enterprises: Drivers of CSR implementation, Motivation for CSR implementation and Barriers to CSR implementation. The 69 papers sourced by [26] covered seventeen countries, including both developed and developing countries, of which most focused on China and the UK. These statistics give an indication as to the limited CSR research in the construction industry globally.

In South Africa only five studies could be sourced regarding CSR and its implementation in the SACI. Of the five studies only two focused on SMEs. These form part of the 69 papers sourced by [26]. The first study conducted by [27] focused on integrating the concept of CSR within South African Quantity Surveying firms as an approach for solving the housing problem for the poor. The second study conducted by [28] focused on the role of partnership in integrating CSR of project stakeholders towards better housing affordability. The third study conducted by [29] primarily investigated and tried to establish the status of Small Medium and Micro-Enterprises (SMMEs) in the built environment in relation to CSR to promote an awareness of the CSR function in the community, promoting SME growth, continues improvement and sustainability. The study conducted by [30] focused on establishing the extent to which construction SMEs in Gauteng, South Africa involve CSR in their practices. Lastly, a study conducted by [31] focused on appraising the current practice of corporate social responsibility on firms operating in the South African construction market.

Using the studies conducted by $[25,26]$ as a benchmark it is evident that no significant study pertaining to the research themes highlighted have been conducted in South Africa particularly from a construction business perspective which includes SMEs who operate in the construction industry. Thus, expanding on the work presented by $[25,26]$ there is a need to investigate the following:

- How do SMEs in the SACI perceive the relationship between the integration of CSR and SBP?

In doing so, it is acknowledged that perceptions form an integral part of this study and therefore it is generally assumed that when conducting research on topics which include concepts such as motivation and perception, a qualitative research approach is 
more appropriate than a quantitative approach [32]. Considering this view, this research, however unconventionally adopts a quantitative research approach in the form of an online questionnaire survey and analysis of the research data using both descriptive (mean, standard deviation, etc.) and inferential (Analysis of Variance ANOVA) statistics. The reason for this is that organisational perceptions regarding the relationship between the integration of CSR and SBP are sourced from the literature review and utilised as variables in the methodology section, allowing the research participants of this study (SME owners) to rate the perceptions based on their personal background and experiences utilising a Likert scale of 1 to 4 . Using this approach, the study established that approximately $75 \%$ of the surveyed SMEs positively perceive that the integration of CSR in their organisations contribute to SBP. Reflecting back on the limited CSR studies conducted in the global construction industry, the findings of this research is a significant contribution highlighting that CSR should be considered as a guiding concept leading to SBP of SMEs not only in the local but also global construction industry.

\section{Literature Review}

To establish whether a relationship exists between the integration of CSR and SBP, by specifically investigating the organisational perceptions of SMEs in the SACI, it is important that the concepts SBP and CSR be correctly defined.

\subsection{Sustainable Business Performance (SBP)}

It is interesting to note that as part of 'Philosophical Investigations', [33] defines the word 'meaning' by the way language is used. It is factual that a word and a term may have a variety of meanings, based on how it is used in the context of language. It is further elaborated by [33] that words and terms may be meaningless, or may have some meaning, or may be full of meaning. Therefore, in the context of this study, firstly the word sustainable is defined, before defining the full phrase sustainable business performance. According to [33], the discussion regarding the precise definition of the word sustainable is a significant concern in the literature. This could explain why a common understanding of the word sustainable is difficult to achieve. Based on the study by [33], the word sustainable literally means 'the ability to sustain'. They further state that the word sustainable is derived from the Latin word sustinere, meaning 'to hold'. Authors such as [34] stipulate that to grasp meaning from the word sustainable, it must refer to renewing or restoring something specific, for example a small construction business, and should incorporate elements such as ethical dimensions of fairness of trade-off between current economic pressures and future needs of a business environment. In addition, ref. [35] refer to the word sustainable as follows:

The long-term maintenance of systems according to environmental, economic and social considerations.

Based on this debate, it is satisfying to note that there are various synonyms or meanings for the word sustainable which, according to [33], may include bear, support, endure or suffer. These meanings establish a clear difference between the words, although they complement each other. However, based on [36] the word sustainable also means 'to be maintained at a certain rate or level', generally referring to the word sustainable as a form of consistency, for example a sustainable business performance. Thus, for the purpose of this study, sustainable will be referred to as maintaining.

With regard to the phrase business performance, the general definition is as follows:

A combination of management and analytic processes that allow the owner-managers of businesses to achieve their predetermined objectives and goals [37].

In adding [38], define business performance as follows:

The operational ability to satisfy the desires of the organisations' major shareholders and it must be assessed to measure the organisations' accomplishments. 
However, with regard to a study conducted by [39] and in the context of this research, the term business performance for small and medium sized construction businesses is defined as:

A phenomenon consisting of a set of attributes focusing on construction SMEs' stakeholders satisfaction, provided in a culture that motivates the construction SME ownermanager to coordinate resources and activities.

With the word sustainable and the phrase business performance adequately defined, it is possible to place them alongside each other to form the term sustainable business performance, which in the context of this study can be defined as follows:

A phenomenon maintaining a set of attributes at a productive level or rate, focusing on the construction SMEs' stakeholder satisfaction provided in a culture that motivates the construction SME owner-manager to coordinate construction resources and activities.

With the term sustainable business performance defined, in Section 2.2 CSR is defined.

\subsection{Corporate Social Responsibility (CSR)}

According to [28], before the 1990s CSR was only vaguely defined and many companies were simply doing good to look good. They elaborate that companies sponsored as many charitable organisations as possible, with the perception that these practices would satisfy most people and would subsequently establish more visibility for their philanthropic efforts. From a construction industry perspective, they are, however, of the opinion that CSR is about organisations making interim commitments to various stakeholders, viewed in the public eye as socially responsible entities. In addition, [40] suggest that CSR signifies a continuous commitment by an organisation, in particular a construction organisation, to act responsibly and ethically and to contribute to sustainable and economic development. According to [40], CSR aims to:

reduce the negative impact of business activities, while maximising the positive impacts, by improving a wide range of societal and environmental problems and contributing to the local community and society at large.

The opinions of [29] concur with [40], explaining that indications of CSR would be that,

the business embraces responsibility for the impact of its activities on the environment, consumers, employees, communities, stakeholders and all other members of the public sphere.

To date, many other authors including [41-44] have attempted to define (CSR). According to [16], the most frequently cited definition for the term CSR as per frequency counts in Google (286), stem from [18] which states that CSR is,

a concept whereby companies integrate social and environmental concerns in their business operations and in their interaction with their stakeholders on a voluntary basis.

\subsection{Relationship between the Integration of CSR and SBP of SMES}

Studies by $[22,29]$ show that research on CSR has predominantly been conducted on larger organisations (not the SME sector), with very little research focused on smaller organisations. There is however compelling evidence in studies by $[11,17,22,45]$ that the integration of CSR can be utilised as a tool to enhance the sustainable business performance of SMEs across all business sectors, inclusive of the construction sector. Thus [15] stress that CSR is regarded as an important business concept, that businesses of all categories (type, size and industry) need to understand and address. They make this claim because global competitiveness is at an all-time high; thus, the integration of CSR is proposed as an effective strategy for sustaining the operations and competitiveness of SMEs. CSR has therefore become increasingly important to the survival and competitiveness of SMEs as it promotes sustainable business performance.

A Study conducted by [46], identifying a positive relationship between the integration of CSR and corporate financial performance (CFP), suggest that businesses inclusive of 
SMEs that implement CSR strategies are more likely to illustrate sustainable business performance. This is supported by $[47,48]$ confirming that socially responsible companies (companies engaging in CSR activities concerning the business stakeholders which include: shareholders, employees, customers, and suppliers, the environment and society, respectively) among other, cultivate positive brand recognition, increase customer loyalty and attract top-tier employees, all of which are vital to achieving increased profitability, long-term financial success and business sustainability. According to [21], CSR strategies implemented by SMEs allow SMEs to produce sustainable business performances which encapsulate excellent financial performances, through various cost reductions, efficient employees and more turnover, resulting in positive growth within SMEs. In addition, Ref. [11] insist that the integration of CSR has a positive impact, influencing the competitiveness and sustainable business performance of SMEs in numerous ways:

Improving their products and services, resulting in improved client satisfaction and loyalty, higher motivation and loyalty of employees, better publicity due to awards received and/or enhanced word-of-mouth references, better corporate image and increased turnover due to competitive advantage gained.

\subsection{Relationship between the Integration of CSR and SBP of Construction SMEs}

It is worth noting that CSR within the global construction industry specifically among property companies in the UK is still viewed as a vague term, thus it is utilised interchangeably with similar, but different terms such as socially responsible investing (SRI), socially responsible property investing (SRPI) and corporate governance (CG) [49]. According to [50] property developers in Malaysia also differ in their opinion regarding the meaning of CSR, as some of them view CSR as conducting businesses as specified by the law and policies, while others view CSR as a concept beyond the specifications of the law and policies in the conduct of the business. According to [49] these differences are due to a lack of a common definition of CSR, particularly in the global construction industry, reducing the theoretical and practical knowledge of true CSR activities among construction organisations. With these differences in the meaning of CSR noted [25] are still of the opinion that the most notable perception pertaining to the integration of CSR in the global construction industry is that it assists in the achievement of sustainability.

This being said, $[25,51]$ are of the opinion that a construction organisation's CSR perception and performance can significantly influence the construction organisation's reputation and affiliation with significant stakeholders, such as employees, customers/clients, investors, government, suppliers and the community at large. It is further stated by [51] that excellent CSR performance will not only enhance a construction company's competitiveness in acquiring better human resources, but will contribute to improving the morale, loyalty, commitment, and productivity of the organisation, contributing significantly to the organisation's SBP. In Sections 2.5 and 2.6 the relationship between the integration of CSR and SBP of construction SMEs in developed as well as developing countries will be discussed.

\subsection{Relationship between the Integration of CSR and SBP of Construction SMEs in Developed Countries}

Findings by [40] suggests that there is a positive relationship between the practice of CSR among SMEs in the Australian construction industry and SBP, as the practice positively contributes to the following: company reputation and image, company efficiency, legal obligations, giving back to the community, longevity of the company, promotes employee loyalty and staff retention, provides a better future for people, and assists to develop skills in the local community. All of these contribute significantly to the SBP of SMEs.

A comparative study conducted by [52] between the United Kingdom (UK) and Turkish construction businesses which include among other SMEs, pertaining to CSR practices, found that there too is a positive relationship between the practice of CSR among the businesses surveyed and SBP, contributing positively to increased business relations 
and new business opportunities. Other contributions include, positive reactions from construction clients; dedication, loyalty, commitment and respect from employees; positive effect on business processes; strengthened company image; increased brand recognition; reputation gain; credibility; improved company prestige; recognition by international credit organisations; improved competitiveness, and remembered as a responsible corporation by business partners.

From a Portuguese perspective it should be noted that SMEs across all industries are of the opinion that an affirmative affiliation does exist between the implementation and practice of CSR in their businesses and SBP, based on the fact that they experience benefits which include a better business reputation with clients, consumers and business partners as well as increasing employee satisfaction, employee motivation and better productivity [53].

\subsection{Relationship between the Integration of CSR and SBP of Construction SMEs in Developing Countries}

According to [54] the practice and integration of CSR in Ghanaian construction SMEs, contribute to SBP, as CSR engagements result in the following tangible benefits: improved competitive advantage; attracting good and quality staff; improved brand image; higher staff retention; reduced regulatory oversight and cost savings. In addition, [55] are also of the opinion that the practice of CSR by SMEs across all Indian sectors, including the construction industry brings about particular benefits that promote SBP, including: better alignment between the SME and consumer concerns; partnership opportunities with transitional companies; improvements in productivity; and improved capacity for learning and innovation.

Findings by [56] suggests that the practice and integration of CSR by SMEs in the Zimbabwean construction industry contributes to SBP, as they positively impact on their business: reputation; marketing of products and services, and improve their business image. The situation seems to be similar in South Africa as [28] suggest that the practice of CSR in construction organisations, which possibly includes SMEs, definitely contribute to the SBP of these organisations, having the following tangible benefits:

"improving financial performance and increasing sales and market share, better risk and crises management, reducing operating costs, increasing workers commitment, motivating and keeping them loyal to the organisation, enhancing brand value and reputation as well as supporting brand positioning, good relations with government and communities, Long-term sustainability for the company and society, a license to operate, long-term return on investment and increasing productivity, enhancing corporate image and clout, and increasing appeal to investors and financial analysts".

\section{Methods}

A quantitative approach was taken for this research. An online questionnaire survey (LimeSurvey) was used to investigate the perception of SMEs in the SACI regarding the relationship between the integration of CSR in their businesses and SBP. The questionnaire survey consisted of two sections. The first required respondents to answer questions pertaining to demographical information and the second required respondents to rate certain statements that describe their internal and external organisational perceptions regarding the relationship between the integration of CSR and SBP.

\subsection{Sample and Questionnaire Administration}

The sample survey participants for the online questionnaire survey was drawn from the national cidb register of contractors, who occupy General Building (GB) and Civil Engineering (CE) classes of work between Grade 1 and Grade 6 (Table 1), and who according to [57] represent the SME cluster in the South African construction industry, with current upper limit tender values, ranging between less than ZAR 1 million to ZAR 20 million. 
To determine a suitable representative sample for this study, the formula by [58], cited in $[59,60]$ was applied:

$$
\text { ss }=z^{2} \times \frac{p(1-p)}{C^{2}}
$$

where;

ss $=$ sample size

$\mathrm{z}=$ standardised variable

$\mathrm{p}=$ percentage picking a choice, expressed as a decimal

$\mathrm{c}=$ confidence interval, expressed as a decimal

To achieve a sample size with a given degree of accuracy, the worst-case percentage picking choice of 50\% was assumed [59-61]; a 95\% confidence level was assumed as in other studies with a significance level of $\alpha=0.05 ; \mathrm{z}=1.96$ at $95 \%$ confidence level; and a confidence interval (c) of $\pm 10 \%$ was taken.

The sample size was computed as follows: ss $=\frac{1.96^{2} \times 0.5(1-0.5)}{0.1^{2}}=96.04$.

Thus, the required sample size for the questionnaire survey is 96 respondents across General Building (GB) and Civil Engineering (CE) contractors registered with the cidb across South Africa, between Grades 1 and 6. This number was required to generate a new sample size from the research population using the following, as suggested in [58]:

$$
\text { New ss }=\frac{\text { ss }}{1+\frac{\mathrm{ss}-1}{\mathrm{pop}}}
$$

where:

pop $=$ population

$$
\text { New ss }=\frac{96.04}{1+\frac{96.04-1}{51636}}
$$

New ss/= 95.86 rounded off to 96

From the above calculations, the sample size is approximately 96 respondents across General Building (GB) and Civil Engineering (CE) contractors registered with the cidb across South Africa, between Grades 1 and 6. According to [62] the response rate is usually in a range of $20-30 \%$. Consequently, it was necessary to adjust the sample size to account for non-responses. Assuming a conservative response rate of $20 \%$, the appropriate sample size to be surveyed was calculated as follows:

$$
\begin{gathered}
\text { Survey ss }=\frac{\text { new ss }}{\text { response rate }} \\
\text { Survey ss }=\frac{96}{0.2}=480
\end{gathered}
$$

The survey sample size was therefore approximately 480 respondents, who, in terms of this study, were randomly selected. Based on the sample size calculated active contact details were obtained from the cidb, for the online questionnaire survey. A cover letter including the link to the online questionnaire survey (LimeSurvey) as seen in Appendix A was sent out via email to all research participants (Table 2). One week after the last cover letters and questionnaires were sent out, $38 \%$ of the targeted sample size indicated their willingness to partake in the study. Participants who did not respond were contacted via telephone calls as a follow-up. Further to the follow-up calls, $71 \%$ of the targeted sample size agreed to participate, however this did not guarantee the rate of questionnaire completion and submission. 
Table 1. Research target population.

\begin{tabular}{|c|c|c|c|c|c|c|c|c|c|c|}
\hline Province & $\begin{array}{c}\text { Western } \\
\text { Cape }\end{array}$ & $\begin{array}{c}\text { Northern } \\
\text { Cape }\end{array}$ & $\begin{array}{l}\text { North } \\
\text { West }\end{array}$ & Mpumalanga & Limpopo & $\begin{array}{c}\text { Kwa } \\
\text { Zulu } \\
\text { Natal }\end{array}$ & Gauteng & $\begin{array}{l}\text { Free } \\
\text { State }\end{array}$ & $\begin{array}{c}\text { Eastern } \\
\text { Cape }\end{array}$ & Total \\
\hline \multicolumn{11}{|l|}{ Cidb } \\
\hline \multicolumn{11}{|l|}{ Grade } \\
\hline $1 \mathrm{~GB}$ & 1828 & 804 & 2910 & 2802 & 3024 & 6901 & 11,154 & 1481 & 2819 & 33,723 \\
\hline $1 \mathrm{CE}$ & 413 & 270 & 972 & 1489 & 1553 & 5289 & 1863 & 842 & 2500 & 15,191 \\
\hline 2 GB & 77 & 25 & 70 & 47 & 43 & 89 & 234 & 29 & 60 & 674 \\
\hline $2 \mathrm{CE}$ & 24 & 15 & 19 & 51 & 27 & 58 & 66 & 33 & 117 & 410 \\
\hline $3 \mathrm{~GB}$ & 27 & 3 & 11 & 10 & 12 & 31 & 58 & 7 & 19 & 178 \\
\hline $3 \mathrm{CE}$ & 22 & 4 & 5 & 25 & 14 & 163 & 31 & 24 & 27 & 315 \\
\hline $4 \mathrm{~GB}$ & 51 & 2 & 15 & 18 & 28 & 37 & 83 & 5 & 25 & 264 \\
\hline $4 \mathrm{CE}$ & 37 & 2 & 11 & 22 & 28 & 78 & 55 & 22 & 36 & 291 \\
\hline 5 GB & 20 & 3 & 0 & 6 & 9 & 15 & 30 & 2 & 4 & 89 \\
\hline $5 \mathrm{CE}$ & 19 & 2 & 8 & 18 & 17 & 51 & 19 & 10 & 13 & 157 \\
\hline $6 \mathrm{~GB}$ & 29 & 2 & 6 & 17 & 14 & 28 & 32 & 5 & 13 & 146 \\
\hline $6 \mathrm{CE}$ & 25 & 7 & 5 & 20 & 19 & 49 & 47 & 8 & 18 & 198 \\
\hline Total & 2572 & 1139 & 4032 & 4525 & 4788 & 12,789 & 13,672 & 2468 & 5651 & 51,636 \\
\hline
\end{tabular}

Table 2. Sample survey participants.

\begin{tabular}{|c|c|c|c|c|c|c|c|c|c|c|}
\hline Province & $\begin{array}{c}\text { Western } \\
\text { Cape }\end{array}$ & $\begin{array}{l}\text { Northern } \\
\text { Cape }\end{array}$ & $\begin{array}{l}\text { North } \\
\text { West }\end{array}$ & Mpumalanga & Limpopo & $\begin{array}{c}\text { Kwa } \\
\text { Zulu } \\
\text { Natal }\end{array}$ & Gauteng & $\begin{array}{l}\text { Free } \\
\text { State }\end{array}$ & $\begin{array}{c}\text { Eastern } \\
\text { Cape }\end{array}$ & Total \\
\hline \multicolumn{11}{|l|}{ Cidb } \\
\hline \multicolumn{11}{|l|}{ Grade } \\
\hline $1 \mathrm{~GB}$ & 16 & 6 & 6 & 6 & 6 & 16 & 16 & 6 & 6 & 84 \\
\hline $1 \mathrm{CE}$ & 16 & 6 & 6 & 6 & 6 & 16 & 16 & 6 & 6 & 84 \\
\hline $2 \mathrm{~GB}$ & 6 & 5 & 5 & 5 & 5 & 6 & 6 & 5 & 5 & 48 \\
\hline $2 \mathrm{CE}$ & 6 & 5 & 5 & 5 & 5 & 6 & 6 & 5 & 5 & 48 \\
\hline $3 \mathrm{~GB}$ & 5 & 2 & 2 & 2 & 2 & 5 & 5 & 2 & 2 & 27 \\
\hline $3 \mathrm{CE}$ & 5 & 2 & 2 & 2 & 2 & 5 & 5 & 2 & 2 & 27 \\
\hline $4 \mathrm{~GB}$ & 5 & 2 & 2 & 2 & 2 & 5 & 5 & 2 & 2 & 27 \\
\hline $4 \mathrm{CE}$ & 5 & 2 & 2 & 2 & 2 & 5 & 5 & 2 & 2 & 27 \\
\hline 5 GB & 5 & 2 & 2 & 2 & 2 & 5 & 5 & 2 & 2 & 27 \\
\hline $5 \mathrm{CE}$ & 5 & 2 & 2 & 2 & 2 & 5 & 5 & 2 & 2 & 27 \\
\hline $6 \mathrm{~GB}$ & 5 & 2 & 2 & 2 & 2 & 5 & 5 & 2 & 2 & 27 \\
\hline $6 \mathrm{CE}$ & 5 & 2 & 2 & 2 & 2 & 5 & 5 & 2 & 2 & 27 \\
\hline Total & 84 & 38 & 38 & 38 & 38 & 84 & 84 & 38 & 38 & 480 \\
\hline
\end{tabular}

The internet-mediated questionnaire survey approach was used to reach a large audience throughout various provincial regions with a wide geographical dispersion. However, some of the respondents' emails bounced back, while some respondents opted out, based on reasons that they were not interested in operating in the construction sector any longer; others simply opted out because they were too busy, among other: prioritizing their business around the COVID 19 pandemic and were unable to attend to the questionnaire. Most of these reasons were received and noted via the follow-up telephone calls that were made to the respondents. To achieve a high response rate from the participants who showed interest to participate in the survey, notifications requesting their response to the questionnaire survey were sent on a weekly basis to enhance their interest for the research and to ensure a good response rate. Of the 480 questionnaires surveys emailed to respondents, 110 were suitably completed and returned; resulting in a response rate of $23 \%$. The questionnaire distribution compared to the responses received for the different provinces is reported in Table 3. 
Table 3. Questionnaire distribution vs. responses received.

\begin{tabular}{cccc}
\hline Province & Distributed & Received & Percentage \\
\hline Western Cape & 84 & 51 & 60.7 \\
Northern Cape & 38 & 4 & 10.5 \\
North West & 38 & 2 & 5.3 \\
Mpumalanga & 38 & 7 & 18.4 \\
Limpopo & 38 & 2 & 5.3 \\
Kwa Zulu Natal & 84 & 11 & 13.1 \\
Gauteng & 84 & 18 & 21.4 \\
Free State & 38 & 3 & 7.9 \\
Eastern Cape & 38 & 12 & 31.6 \\
Total & $\mathbf{4 8 0}$ & $\mathbf{1 1 0}$ & $\mathbf{2 2 . 9}$ \\
\hline
\end{tabular}

\subsection{Data Analysis}

The quantitative data collected generally conformed to scale measurements, as the research responses were ratings measured on a four-point Likert scale, as indicated in Table 4. Both descriptive and inferential statistical techniques were used, Descriptive statistics presented are in the form of percentiles, frequencies, and mean scores (MSs). Inferential statistics are represented using Analysis of Variance (ANOVA). All the quantitative statistics were obtained using a Statistical Package for Social Sciences (SPSS).

Table 4. Definition of terms for the four-point Likert-scale.

\begin{tabular}{cc}
\hline Mean Score Range & Meaning \\
\hline $1.00-1.75$ & $1=$ Strongly Disagree \\
$1.76-2.50$ & $2=$ Disagree \\
$2.51-3.25$ & $3=$ Agree \\
$3.26-4.00$ & $4=$ Strongly Agree \\
\hline
\end{tabular}

\section{Results and Discussion}

This section presents and analysis the data collected for this study. The first set of data presented and analysed is the demographical information pertaining to the research participants, followed by the data representing the internal and external organisational perceptions of the respondents (SMEs), regarding the integration of CSR and SBP, as well as data reflecting the ANOVA pertaining to the responses of the research participants.

\subsection{Respondents Demographical Information}

\subsubsection{Construction Related Experience and Education of SME Owner}

Examining the data in Table 5 it is clear that of the SME owners who partook in the questionnaire survey $39 \%$ obtained between 1 and 5 years of construction related experience; $23 \%$ have acquired between 6 and 10 years of construction related experience; another $23 \%$ have obtained between 11 and 15 years of experience; with just $7 \%$ acquiring between 16 to 20 years of construction related experience, leaving $8 \%$ of SME owners securing between 21 and 25 years of construction related experience. Further analysing the data, it is clear that approximately $61 \%$ of the SME owners have an average of (16 years) of construction related experience, indicating significant experience in the construction sector, contributing to the validity and reliability of their responses.

The data in Table 6 shows that roughly $71 \%$ of the SME owners have obtained some form of construction related education and training qualification and about $42 \%$ have obtained a construction related qualifications from various universities across South Africa. Of the $42 \%$, about $15 \%$ of SME owners obtained a National Diploma in Civil Engineering; $9 \%$ acquired a National Diploma in Building; $6 \%$ qualified with a Bachelor of Technology in Construction Management; 4\% obtained a Bachelor of Technology in Civil Engineering; $3 \%$ acquired a Bachelor of Technology in Quantity Surveying; $2 \%$ qualified with a Bachelor of Science in Construction Management; $1 \%$ obtained a Bachelor of Science in Civil 
Engineering; with another 1\% acquiring a National Diploma in Architecture; and lastly, 1\% acquiring a Master's of Science in Project Management (Construction).

Table 5. Years of construction related experience pertaining to SME owners.

\begin{tabular}{ccccc}
\hline Variable & & Frequency & Percent & Cumulative Percent \\
\hline Years of construction related & $1-5$ yrs & 43 & 39.1 & 39.1 \\
experience pertaining to & $6-10$ yrs & 25 & 22.7 & 61.8 \\
SME owners' & $11-15$ yrs & 25 & 22.7 & 84.5 \\
& $16-20$ yrs & 8 & 7.3 & 91.8 \\
& $21-25$ yrs & 9 & 8.2 & $\mathbf{1 0 0}$ \\
& Total & $\mathbf{1 1 0}$ & $\mathbf{1 0 0}$ & \\
\hline
\end{tabular}

Table 6. Construction related education and training of SME owners.

\begin{tabular}{|c|c|c|}
\hline Variab & & Approximate Percentage \\
\hline \multirow{11}{*}{$\begin{array}{l}\text { Construction related (university) } \\
\text { education and training of } \\
\text { SME owner: }\end{array}$} & ND Civil Engineering & $15 \%$ \\
\hline & ND Building & $9 \%$ \\
\hline & BTech Construction & \\
\hline & Management & $6 \%$ \\
\hline & BTech Civil Engineering & $4 \%$ \\
\hline & BTech Quantity Surveying & $3 \%$ \\
\hline & BSc Construction & $2 \%$ \\
\hline & Management & \\
\hline & BSc Civil Engineering & $1 \%$ \\
\hline & ND Architecture & $1 \%$ \\
\hline & $\begin{array}{l}\text { MSc Project Management } \\
\text { (Construction) }\end{array}$ & $1 \%$ \\
\hline \multirow{10}{*}{$\begin{array}{l}\text { Construction related (TVET) } \\
\text { education and training of } \\
\text { SME owner: }\end{array}$} & Qualified Bricklayer & $16 \%$ \\
\hline & $\begin{array}{l}\text { Cert. Building and Civil } \\
\text { Engineering }\end{array}$ & $3 \%$ \\
\hline & Qualified Tiler & $2 \%$ \\
\hline & Qualified Carpenter & $2 \%$ \\
\hline & Qualified Plasterer & $1 \%$ \\
\hline & Qualified Plumber & $1 \%$ \\
\hline & $\begin{array}{c}\text { Cert. Construction Project } \\
\text { Management }\end{array}$ & $1 \%$ \\
\hline & Cert. Road Construction & $1 \%$ \\
\hline & $\begin{array}{l}\text { Cert. Construction } \\
\text { Maintenance }\end{array}$ & $1 \%$ \\
\hline & $\begin{array}{c}\text { Cert. Contractor } \\
\text { Development Programme }\end{array}$ & $1 \%$ \\
\hline \multirow{5}{*}{$\begin{array}{l}\text { Other education and training of } \\
\text { SME owner: }\end{array}$} & Qualifications in: Business & \\
\hline & Management; Education; & $23 \%$ \\
\hline & Internet Technology, and & $23 \%$ \\
\hline & Mechanical Engineering & \\
\hline & Matric Certificate & $3 \%$ \\
\hline $\begin{array}{l}\text { SME owner with } \\
\text { no Qualification: }\end{array}$ & None & $3 \%$ \\
\hline
\end{tabular}

In addition, roughly $29 \%$ of the SME owners who make up the $71 \%$ have obtained a construction related qualifications from various public and private technical and vocational education and training colleges (TVET) across South Africa. Of the 29\%, approximately $16 \%$ of SME owners obtained a qualification in Bricklaying; 3\% qualified with a Certificate in Building and Civil Engineering; $2 \%$ acquired a qualification in Tiling; $2 \%$ obtained a qualification in Carpentry; $1 \%$ in Plastering; $1 \%$ in Plumbing; with $1 \%$ acquiring a Certificate in 
Construction Project Management; 1\% obtaining a Certificate in Road Construction, 1\% Certificate in Construction Maintenance; and lastly $1 \%$ obtaining a certificate by participating in contractor development programmes (CDPs).

Approximately $23 \%$ of the SME owners obtained other qualifications that are not construction specific, but rather include among other, fields of Business Management, Education, Internet Technology, Mechanical Engineering, as well as Electrical Engineering. Approximately 3\% of the remaining $29 \%$ of SME owners indicated that they obtained only a Matric Certificate, with roughly 3\% of SME owners indicating that they have acquired no qualification entirely. It can thus be deduced from the above analysis that the respondents representations are from SME owners who are mostly qualified and competent, and whose judgements and information provided towards the questionnaire survey can be considered reliable and valid.

\subsubsection{Operational Years of SMEs'}

Results presented in Table 7 indicate that approximately $52 \%$ of the SMEs have been operational between 1 and 5 years 25\% between 6 and 10 years, and 14\% between 11 and 15 years. Only 3\% have been operational between 16 and 20 years, 3\% between 21 and 25 years and $5 \%$ have been operational for more than 25 years.

Table 7. Operational years of SMEs'.

\begin{tabular}{|c|c|c|c|c|}
\hline \multicolumn{2}{|c|}{ Variable } & \multirow{2}{*}{$\frac{\text { Frequency }}{57}$} & \multirow{2}{*}{$\frac{\text { Percent }}{51.8}$} & \multirow{2}{*}{$\frac{\text { Cumulative Percent }}{51.8}$} \\
\hline \multirow{7}{*}{$\begin{array}{l}\text { Number of years } \\
\text { the SME owners' } \\
\text { organisation has } \\
\text { been operational: }\end{array}$} & $1-5$ yrs & & & \\
\hline & $6-10$ yrs & 27 & 24.5 & 76.4 \\
\hline & $11-15$ yrs & 15 & 13.6 & 90.0 \\
\hline & $16-20$ yrs & 3 & 2.7 & 92.7 \\
\hline & $21-25$ yrs & 3 & 2.7 & 95.5 \\
\hline & More than 25 yrs & 5 & 4.5 & 100.0 \\
\hline & Total & 110 & 100 & \\
\hline
\end{tabular}

\subsubsection{SMEs Cidb Class of Work and Cidb Grade}

In addition to the data concerning the SMEs operational years Table 8 shows that nearly $45 \%$ of the SMEs, are registered for both the GB and CE classes of work $28 \%$ in the CE class of work and $26 \%$ of SMEs registered as GB contractors. In terms of the SMEs cidb grade, the data too revealed in Table 9 that roughly $42 \%$ of the SMEs surveyed are grade 1 contractors; nearly $24 \%$ are grade 2 contractors; $9 \%$ of the SMEs stipulated that they are registered as grade 3 contractors, with approximately $12 \%$ indicating that they are registered as grade 4 s. Leaving almost $6 \%$ of the SMEs registered as grade 5 contractors, and $8 \%$ as grade 6 contractors, respectively. The results for this particular section of the data clearly indicate that all the SMEs who partook in this study comply with the research delineation focusing on GB and CE contractors, registered on the cidb register of contractors, between Grades 1 to 6 as Grades 1 to 6 is considered to represent the SME cluster as described by [57].

Table 8. SMEs' cidb class of work.

\begin{tabular}{ccccc}
\hline Variable & & Frequency & Percent & Cumulative Percent \\
\hline cidb class of work & Both & 50 & 45.5 & 45.5 \\
that the SMEs & CE & 31 & 28.2 & 73.6 \\
organisation is & GB & 29 & 26.4 & 100.0 \\
registered in: & Total & $\mathbf{1 1 0}$ & $\mathbf{1 0 0}$ & \\
\hline
\end{tabular}


Table 9. SMEs' cidb grade.

\begin{tabular}{ccccc}
\hline \multicolumn{1}{c}{ Variable } & & Frequency & Percent & Cumulative Percent \\
\hline & Grade 1 & 46 & 41.8 & 41.8 \\
& Grade 2 & 26 & 23.6 & 65.5 \\
cidb grade that the & Grade 3 & 10 & 9.1 & 74.5 \\
SME organisation & Grade 4 & 13 & 11.8 & 86.4 \\
is registered in: & Grade 5 & 6 & 5.5 & 91.8 \\
& Grade 6 & 9 & 8.2 & 100.0 \\
\hline
\end{tabular}

\subsection{SMEs Perception Pertaining to the Relationship between the Integration of CSR and SBP}

As a means to identify and ascertain how SMEs in the SACI perceive the relationship between the integration of CSR and SBP, SMEs were asked to give their perceptions from both an internal and external organisational perspective. A spot check, of the data specific to the SMEs' perceptions of the relationship between the integration of CSR and SBP underwent a reliability analysis utilising Cronbach's alpha. According to [63] a Cronbach's alpha coefficient should be interpreted as highly reliable at (0.90) and above; moderately reliable at (0.80) and above; and low reliability at (0.70) and above. In addition, [64] stated that a Cronbach's alpha above $(0.70)$ is considered acceptable. The results presented in Appendix B shows that the internal consistency for the SMEs' perceptions based on the relationship between the integration of CSR and SBP from both an internal and external perspective is highly reliable and acceptable with Cronbach's alpha values all above 0.70 and the total Cronbach alpha coefficient at 0.987 .

Further to the reliability of the data, Table 10 indicates the descriptive data pertaining to the way in which SMEs perceive the relationship between the integration of CSR and SBP from an internal and external organisational perspective. All 29 variables listed in Table 10 have mean scores (MSs) between (2.51) and (3.25), indicating that SMEs in the SACI agree with all the variables. This finding is supported by [15] who acknowledge that based on global competitiveness CSR has become increasingly important to the survival and competitiveness of SMEs promoting SBP. This is so, based on the fact that society and stakeholder communities situated around businesses such as SMEs are becoming increasingly aware of the social costs and risks of businesses. Consequently, business owners globally including, construction business owners are reconfiguring their business models towards social responsibility and in so doing become attractive to the surrounding society and stakeholder communities, affording their businesses the opportunity to gain competitive advantage, ultimately contributing to their SBP [25]. These views are also supported by stakeholder theory which broadens the objectives of a business from profit maximisation to the satisfaction of stakeholder needs $[9,10,65,66]$.

Further to the views of $[9,10,15,25,65,66]$ and interpreting the data in terms of the top four MSs relative to the SMEs' perceptions regarding the relationship between the integration of CSR and SBP from an internal organisational perspective, it is evident that "CSR improves the organisation's prestige" was ranked the highest (MS $=2.96)$, followed by "CSR increases the organisational ability to attract good and quality staff" (MS $=2.95$ ); "CSR improves the organisation's efficiency" (MS = 2.94) and "CSR improves employee dedication, motivation, loyalty, commitment, respect, and efficiency" (MS = 2.93). These findings coincide with the views of $[25,52,54]$. However, although SMEs also agree with the fact that "CSR improves their organisation's financial performance" (MS $=2.85)$, and "the organisations products and services" (MS $=2.83)$, these two variables with regard to the SMEs internal organisational perceptions were ranked the lowest. In addition to the MSs and ranking of the variables relative to all the "internal organisational perceptions", it is evident from the total average percentages, that approximately $74 \%$ of the SMEs agree that the integration of CSR positively contributes to SBP.

Analysing the data in terms of the top four MSs relative to the SMEs perceptions regarding the relationship between the integration of CSR and SBP from an external 
organisational perspective, it is evident that: "CSR positively contributes to the credibility of the organisation" was ranked the highest (MS = 2.99), followed by "CSR improves the organisation's corporate image and reputation with various stakeholders (employees, customers/clients, investors, government, suppliers and the community)" (MS $=2.98$ ); "CSR increases business relations and new business opportunity" (MS = 2.97); and "CSR positively contributes to giving back to the community" (MS = 2.96). These finding also coincide with the opinions and views of $[25,28,52,54,56]$. Conversely, although SMEs still agree with the fact that "CSR reduces regulatory oversight" $(\mathrm{MS}=2.79)$ and "allows the organisation to access funding opportunities" (MS = 2.77); these two variables with regard to the SMEs external organisational perceptions were ranked the lowest. Adding to the MSs and ranking of the variables relative to all the "external organisational perceptions", approximately $75 \%$ of the SMEs agree that the integration of CSR positively contributes to SBP.

Table 10. Frequencies and Descriptive Statistics: SMEs perceptions based on the relationship between the integration of CSR and SBP.

\begin{tabular}{|c|c|c|c|c|c|c|c|c|}
\hline \multirow{3}{*}{ Coding } & \multirow{3}{*}{ Variables } & \multicolumn{4}{|c|}{ Response (\%) } & \multirow{3}{*}{ Mean } & \multirow{3}{*}{ Std. Dev. } & \multirow{3}{*}{ Rank } \\
\hline & & $\begin{array}{l}\text { Strongly } \\
\text { Disagree }\end{array}$ & Disagree & Agree & $\begin{array}{l}\text { Strongly } \\
\text { Agree }\end{array}$ & & & \\
\hline & & 1 & 2 & 3 & 4 & & & \\
\hline \multicolumn{9}{|c|}{$\begin{array}{c}\text { Internal Organisational } \\
\text { Perceptions }\end{array}$} \\
\hline C41_A_F & $\begin{array}{l}\text { Integrating CSR improves the } \\
\text { organisation's prestige, } \\
\text { contributing to SBP }\end{array}$ & 6.4 & 18.2 & 48.2 & 27.3 & 2.96 & 0.845 & 1 \\
\hline C41_A_H & $\begin{array}{l}\text { Integrating CSR increases the } \\
\text { organisational ability to attract } \\
\text { good and quality staff } \\
\text { contributing to SBP. }\end{array}$ & 8.2 & 15.5 & 50.0 & 26.4 & 2.95 & 0.866 & 2 \\
\hline C41_A_C & $\begin{array}{l}\text { Integrating CSR improves the } \\
\text { organisation's efficiency } \\
\text { allowing for SBP }\end{array}$ & 5.5 & 19.1 & 51.8 & 23.6 & 2.94 & 0.805 & 3 \\
\hline C41_A_B & $\begin{array}{l}\text { Integrating CSR improves } \\
\text { employee dedication, motivation, } \\
\text { loyalty, commitment, respect, and } \\
\text { efficiency that contributes to SBP }\end{array}$ & 4.5 & 20.0 & 53.6 & 21.8 & 2.93 & 0.775 & 4 \\
\hline C41_A_L & $\begin{array}{l}\text { Integrating CSR improves the } \\
\text { organisation's risk and crises } \\
\text { management contributing to SBP }\end{array}$ & 5.5 & 20.9 & 50.0 & 23.6 & 2.92 & 0.814 & 5 \\
\hline C41_A_G & $\begin{array}{l}\text { Integrating CSR allows for } \\
\text { long-term return on investment and } \\
\text { increase in productivity } \\
\text { contributing to SBP }\end{array}$ & 6.4 & 20.0 & 49.1 & 24.5 & 2.92 & 0.836 & 6 \\
\hline C41_A_M & $\begin{array}{l}\text { Integrating CSR allows for } \\
\text { long-term sustainability of the } \\
\text { organisation and society } \\
\text { contributing to SBP }\end{array}$ & 7.3 & 17.3 & 52.7 & 22.7 & 2.91 & 0.830 & 7 \\
\hline C41_A_J & $\begin{array}{l}\text { Integrating CSR improves the } \\
\text { organisation's capacity for learning } \\
\text { and innovation, ultimately } \\
\text { allowing for SBP }\end{array}$ & 8.2 & 17.3 & 52.7 & 21.8 & 2.88 & 0.843 & 8 \\
\hline C41_A_I & $\begin{array}{l}\text { Integrating CSR improves } \\
\text { operating cost reductions that } \\
\text { contributes to SBP }\end{array}$ & 5.5 & 22.7 & 50.9 & 20.9 & 2.87 & 0.803 & 9 \\
\hline C41_A_A & $\begin{array}{l}\text { Integrating CSR positively impacts } \\
\text { the organisations business } \\
\text { processes, which contributes to SBP }\end{array}$ & 6.4 & 18.2 & 58.2 & 17.3 & 2.86 & 0.772 & 10 \\
\hline
\end{tabular}


Table 10. Cont.

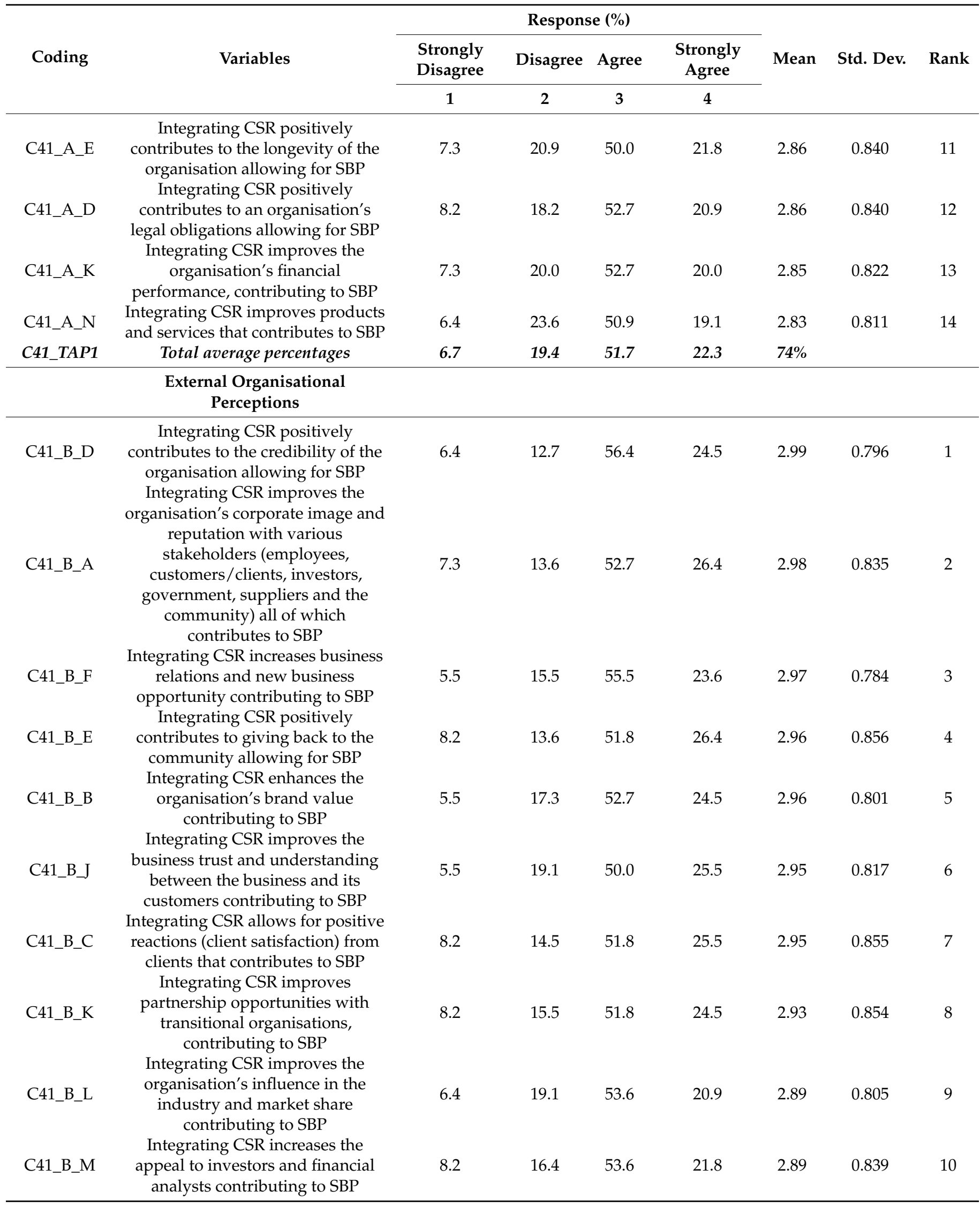


Table 10. Cont.

\begin{tabular}{|c|c|c|c|c|c|c|c|c|}
\hline \multirow{3}{*}{ Coding } & \multirow{3}{*}{ Variables } & \multicolumn{4}{|c|}{ Response (\%) } & \multirow{3}{*}{ Mean } & \multirow{3}{*}{ Std. Dev. } & \multirow{3}{*}{ Rank } \\
\hline & & $\begin{array}{l}\text { Strongly } \\
\text { Disagree }\end{array}$ & Disagree & Agree & $\begin{array}{l}\text { Strongly } \\
\text { Agree }\end{array}$ & & & \\
\hline & & 1 & 2 & 3 & 4 & & & \\
\hline C41_B_H & $\begin{array}{c}\text { Integrating CSR improves the } \\
\text { organisation's competitiveness } \\
\text { ultimately allowing better turnover } \\
\text { which contributes to SBP }\end{array}$ & 9.1 & 18.2 & 50.9 & 21.8 & 2.85 & 0.866 & 11 \\
\hline C41_B_G & $\begin{array}{l}\text { Integrating CSR allows for } \\
\text { organisations to receive recognition } \\
\text { by international credit } \\
\text { organisations, contributing to SBP }\end{array}$ & 10.0 & 17.3 & 50.9 & 21.8 & 2.85 & 0.880 & 12 \\
\hline C41_B_O & $\begin{array}{l}\text { Integrating CSR improves client } \\
\text { retention that contributes to SBP }\end{array}$ & 7.3 & 21.8 & 51.8 & 19.1 & 2.83 & 0.822 & 13 \\
\hline C41_B_I & $\begin{array}{l}\text { Integrating CSR reduces regulatory } \\
\text { oversight which contributes to SBP }\end{array}$ & 7.3 & 25.5 & 48.2 & 19.1 & 2.79 & 0.836 & 14 \\
\hline C41_B_N & $\begin{array}{l}\text { Integrating CSR allows the } \\
\text { organisation to access funding } \\
\text { opportunities contributing to SBP }\end{array}$ & 10.0 & 21.8 & 49.1 & 19.1 & 2.77 & 0.874 & 15 \\
\hline C41_TAP2 & Total average percentages & 7.5 & 17.5 & 52.1 & 23.0 & 75.1 & & \\
\hline
\end{tabular}

\subsection{ANOVA: SMEs Perceptions Based on the Relationship between the Integration of CSR and SBP}

Further to the descriptive statistics obtained in Table 10, an ANOVA test was conducted. The ANOVA test results reported in Tables 11-13 confirms that there is no statistically significant difference between the SMEs and their internal and external organisational perceptions based on the relationship between the integration of CSR and SBP: $\mathrm{F}(5,104)=0.62, p=0.68$, and the calculated eta squared effect of size was small with a value of 0.03 . The ANOVA results imply that although SEs and MEs are categorised differently in terms of their cidb grade and their upper limit of tender value range as documented by [57] the two groups of contractors similarly perceive that a positive relationship between the integration of CSR and SBP exists.

Table 11. Statistics of SMEs perceptions based on the relationship between the integration of CSR and SBP.

\begin{tabular}{|c|c|c|c|c|c|c|c|c|}
\hline \multirow{2}{*}{ SMEs } & \multirow{2}{*}{$\mathbf{N}$} & \multirow{2}{*}{ Mean } & \multirow{2}{*}{ Std. Dev. } & \multirow{2}{*}{ Std. Error } & \multicolumn{2}{|c|}{ 95\% Confidence Interval for Mean } & \multirow{2}{*}{ Minimum } & \multirow{2}{*}{ Maximum } \\
\hline & & & & & Lower Bound & Upper Bound & & \\
\hline Grade 1 & 46 & 3.00 & 0.802 & 0.118 & 2.77 & 3.24 & 1 & 4 \\
\hline Grade 2 & 26 & 2.73 & 0.731 & 0.143 & 2.44 & 3.03 & 1 & 4 \\
\hline Grade 3 & 10 & 2.91 & 0.512 & 0.162 & 2.54 & 3.28 & 2 & 4 \\
\hline Grade 4 & 13 & 3.01 & 0.521 & 0.145 & 2.69 & 3.32 & 2 & 4 \\
\hline Grade 5 & 6 & 2.80 & 0.380 & 0.155 & 2.40 & 3.20 & 2 & 3 \\
\hline Grade 6 & 9 & 2.77 & 0.772 & 0.257 & 2.17 & 3.36 & 1 & 4 \\
\hline Total & 110 & 2.90 & 0.710 & 0.068 & 2.77 & 3.03 & 1 & 4 \\
\hline
\end{tabular}

Table 12. Test of homogeneity of variances.

\begin{tabular}{cccc}
\hline Levene Statistic & df1 & df2 & Sig. \\
\hline 1.108 & 5 & 104 & 0.361 \\
\hline
\end{tabular}


Table 13. ANOVA on SMEs perceptions based on the relationship between the integration of CSR and SBP.

\begin{tabular}{cccccc}
\hline & Sum of Squares & df & Mean Square & F & Sig. \\
\hline Between Groups & 1.596 & 5 & 0.319 & 0.622 & 0.683 \\
Within Groups & 53.365 & 104 & 0.513 & & \\
Total & $\mathbf{5 4 . 9 6 0}$ & $\mathbf{1 0 9}$ & & & \\
\hline
\end{tabular}

\section{Conclusions}

This study documents that although SMEs across all sectors in South Africa employ $47 \%$ of the workforce, contribute to more than $20 \%$ of GDP and pay approximately $6 \%$ of all corporate taxes, it is interesting to note that $70-80 \%$ of construction SMEs fail within their first five years of existence. This raises huge concerns regarding the sustainability of construction SMEs in South Africa; the livelihoods of the people they employ, as well as their immense contribution towards the economy. In an attempt to address this, it should be noted that limited research considering CSR and its link to stakeholder theory as a driver to the SBP of SMEs in the SACI exist, hence this study explored the concept of CSR, by investigating the perceptions of SMEs in the SACI relative to the relationship between the integration of CSR and SBP. The findings indicate that the surveyed SMEs within the SACI perceive that a positive relationship exists between the integration of CSR within their businesses and SBP from both an internal and external perspective. The findings further answers the research question located in Section 1, indicating that the surveyed SMEs within the SACI perceive that the practice of CSR within their businesses among other: improves their prestige; increases their ability to attract good and quality staff; improves their efficiency; contributes to their credibility, and improves their corporate image and reputation with various stakeholders (employees, customers/clients, investors, government, suppliers and the community), all of which contributes to SBP. These findings coincide with the views of [25] who are of the opinion that a positive relationship between the integration of CSR and SBP will exist because society and stakeholder communities situated around businesses, such as SMEs in the SACI are becoming increasingly aware of the social costs and risks of businesses. Hence, business owners are reconfiguring their business models towards social responsibility and in so doing attract and the surrounding society and stakeholder communities, affording their businesses the opportunity to gain a competitive advantage, which ultimately contributes to their SBP. The findings of this study, also coincide with research conducted by [67] confirming that CSR practices by organisations directed at internal stakeholders, such as human resources, and/or environmentally friendly behaviours that can affect external stakeholders, including local communities, ultimately creates new markets, improving the organisations' profitability and strengthens their competitive positioning. Considering the aforementioned the theoretical implication of this study is that other than the lack of: SME owner managers' management knowledge (planning capacity, resourcing, leadership and con-trolling capacity); business knowledge and self-knowledge; industry experience in the chosen area of business such as construction; business acumen, aptitude, and entrepreneurial mind-set to form and raise a successful enterprise, the integration of CSR within SMEs in the SACI is highly likely to result in their SBP as suggested by $[9,10]$, mitigating the unsustainable trajectory of SMEs in the SACI, and affording SMEs in the SACI the opportunity to positively contribute towards the South African economy. Acknowledging this implication, it is therefore recommended that government agencies such as the construction industry development board (cidb) embed CSR education within contractor development programs, linking the practice of CSR to the contractor grading system. This will assist in establishing a CSR culture leading to more SBP of SMEs, enabling sustainable business growth and maturity. To support this recommendation further research is needed in terms of identifying and establishing appropriate CSR modules that could be embedded in contractor development programs aimed at developing SMEs in the SACI. In addition, it is also recommended that a similar 
study utilising either a qualitative or a mixed-method research approach be conducted to obtain further findings, strengthen and adding to the debate regarding the relationship between the integration of CSR and SBP, particularly directed at achieving SBP of SMEs in the SACI.

Limitations, encountered in this research relate to the fact that the questionnaire survey was only administered to SMEs in the SACI, who are registered on the cidb register of contractors between Grade1 GB and/or CE and Grade 6 GB and/or CE. This is therefore considered as a limitation, since the results may only be valid for the South African context, though the generic methodology and data analysis techniques can be replicated for other countries. Another limitation was the difficulty in collecting data during the COVID-19 pandemic.as many SMEs in the SACI prioritised their business survival over research participation, leading to time, administrative and financial constraints experienced during the study. Despite this, sufficient data was obtained in order to validate the findings particularly the organisational perceptions of SMEs in the SACI relative to the relationship between the integration of CSR and SBP, ultimately satisfying the aim of the study.

Author Contributions: Conceptualization, L.W.; methodology, L.W.; software, L.W.; validation, L.W.; formal analysis, L.W.; investigation, L.W.; resources, L.W.; data curation, L.W.; writing-original draft preparation, L.W.; writing - review and editing, J.A.F. and R.H.; visualization, L.W.; supervision, J.A.F. and R.H.; project administration, L.W. All authors have read and agreed to the published version of the manuscript.

Funding: This research was funded by the University (Cape Peninsula University of Technology) Capacity Development Grant (UCDG) Improvement of Qualification Programme (IQP): PD-2020-000198.

Institutional Review Board Statement: The study was conducted according to the guidelines of the Declaration of Helsinki, and approved by the Engineering and the Built Environment Ethics Committee of the CAPE PENINSULA UNIVERSITY OF TECHNOLOGY (18 February 2020).

Data Availability Statement: The data presented in this study are available upon reasonable request from the corresponding author.

Conflicts of Interest: The authors declare no conflict of interest. The funders had no role in the design of the study; in the collection, analyses, or interpretation of data; in the writing of the manuscript, or in the decision to publish the results.

\section{Appendix A. Cover Letter and Link to Questionnaire Survey}

Civil Engineering Department

Faculty of Engineering and the Built Environment

Cape Peninsula University of Technology

Symphony way Bellville, 7535

E-mail: wentzell@cput.ac.za

Dear Sir/Mam,

RE: DOCTORAL (PHD) RESEARCH ON SUSTAINABLE BUSINESS PERFORMANCE OF SMES IN THE SOUTH AFRICAN CONSTRUCTION INDUSTRY

The Faculty of Engineering and the Built Environment at the Cape Peninsula University of Technology (CPUT) is aware and in support of this research aimed at developing a corporate social responsibility (CSR) indicator model to achieve sustainable business performance of SMEs in the South African construction industry.

This questionnaire is a significant part of the research project. We do appreciate that the questionnaire will take approximately $20 \mathrm{~min}$ of your precious time, but without your kind and expert input, the research objectives cannot be realised.

Kindly accept our utmost assurance that all answers and information provided shall be treated with utmost confidentiality and used for academic purposes only.

Should you have any question(s) or would like further information, please do not hesitate to contact me on 0722835398 or e-mail at wentzell@cput.ac.za 
Thank you very much for your valuable time taken to answer the questions and for your kind assistance.

Lance Wentzel

(Doctoral Research Student)

Questionnaire Survey Link: http:/ / bit.ly/SBP_SMS

Accessed Date: 31 January 2021

\section{Appendix B}

Table A1. Reliability Test-SMEs perceptions based on the relationship between the integration of CSR and sustainable business performance.

\begin{tabular}{|c|c|c|c|c|}
\hline Coding & Variable & $\begin{array}{l}\text { Corrected Item-Total } \\
\text { Correlation }\end{array}$ & $\begin{array}{l}\text { Cronbach's Alpha If } \\
\text { Item Deleted }\end{array}$ & $\begin{array}{l}\text { Total Cronbach's } \\
\text { Alpha Coefficient }\end{array}$ \\
\hline \multicolumn{5}{|c|}{ Internal Organisational Perceptions } \\
\hline C41_A_A & $\begin{array}{l}\text { CSR positively impacts the } \\
\text { organisations business processes, } \\
\text { which contributes to SBP }\end{array}$ & 0.641 & 0.987 & \\
\hline C41_A_B & $\begin{array}{l}\text { CSR improves employee dedication, } \\
\text { motivation, loyalty, commitment, } \\
\text { respect, and efficiency that } \\
\text { contributes to SBP }\end{array}$ & 0.765 & 0.987 & \\
\hline C41_A_C & $\begin{array}{l}\text { CSR improves the organisation's } \\
\text { efficiency allowing for SBP }\end{array}$ & 0.825 & 0.987 & \\
\hline C41_A_D & $\begin{array}{c}\text { CSR positively contributes to an } \\
\text { organisation's legal obligations } \\
\text { allowing for SBP }\end{array}$ & 0.844 & 0.987 & \\
\hline C41_A_E & $\begin{array}{l}\text { CSR positively contributes to the } \\
\text { longevity of the organisation } \\
\text { allowing for SBP }\end{array}$ & 0.837 & 0.987 & \\
\hline C41_A_F & $\begin{array}{l}\text { CSR improves the organisation's } \\
\text { prestige, contributing to SBP }\end{array}$ & 0.811 & 0.987 & \\
\hline C41_A_G & $\begin{array}{l}\text { CSR allows for long-term return on } \\
\text { investment and increase in } \\
\text { productivity contributing to SBP }\end{array}$ & 0.868 & 0.987 & \\
\hline C41_A_H & $\begin{array}{l}\text { CSR increases the organisational } \\
\text { ability to attract good and quality staff }\end{array}$ & 0.872 & 0.987 & \\
\hline C41_A_I & $\begin{array}{l}\text { CSR improves operating cost } \\
\text { reductions that contributes to SBP }\end{array}$ & 0.867 & 0.987 & \\
\hline C41_A_J & $\begin{array}{l}\text { CSR improves the organisation's } \\
\text { capacity for learning and innovation, } \\
\text { ultimately allowing for SBP }\end{array}$ & 0.844 & 0.987 & \\
\hline C41_A_K & $\begin{array}{l}\text { CSR improves the organisation's } \\
\text { financial performance, } \\
\text { contributing to SBP }\end{array}$ & 0.861 & 0.987 & \\
\hline C41_A_L & $\begin{array}{l}\text { CSR improves the organisation's risk } \\
\text { and crises management } \\
\text { contributing to SBP }\end{array}$ & 0.870 & 0.987 & \\
\hline C41_A_M & $\begin{array}{l}\text { CSR allows for long-term } \\
\text { sustainability of the organisation and } \\
\text { society contributing to SBP }\end{array}$ & 0.879 & 0.986 & \\
\hline C41_A_N & $\begin{array}{l}\text { CSR improves products and services } \\
\text { that contributes to SBP }\end{array}$ & 0.888 & 0.986 & \\
\hline
\end{tabular}


Table A1. Cont.

\begin{tabular}{|c|c|c|c|c|}
\hline Coding & Variable & $\begin{array}{l}\text { Corrected Item-Total } \\
\text { Correlation }\end{array}$ & $\begin{array}{l}\text { Cronbach's Alpha If } \\
\text { Item Deleted }\end{array}$ & $\begin{array}{l}\text { Total Cronbach's } \\
\text { Alpha Coefficient }\end{array}$ \\
\hline & External Organisational Perceptions & & & $\underline{0.987}$ \\
\hline C41_B_A & $\begin{array}{l}\text { CSR improves the organisation's } \\
\text { corporate image and reputation with } \\
\text { various stakeholders (employees, } \\
\text { customers/clients, investors, } \\
\text { government, suppliers and the } \\
\text { community) all of which } \\
\text { contributes to SBP }\end{array}$ & 0.832 & 0.987 & \\
\hline C41_B_B & $\begin{array}{l}\text { CSR enhances the organisation's } \\
\text { brand value contributing to SBP } \\
\text { CSR allows for positive reactions }\end{array}$ & 0.851 & 0.987 & \\
\hline C41_B_C & $\begin{array}{l}\text { (client satisfaction) from clients that } \\
\text { contributes to SBP }\end{array}$ & 0.849 & 0.987 & \\
\hline C41_B_D & $\begin{array}{l}\text { CSR positively contributes to the } \\
\text { credibility of the organisation } \\
\text { allowing for SBP }\end{array}$ & 0.836 & 0.987 & \\
\hline C41_B_E & $\begin{array}{l}\text { CSR positively contributes to giving } \\
\text { back to the community } \\
\text { allowing for SBP }\end{array}$ & 0.829 & 0.987 & \\
\hline C41_B_F & $\begin{array}{l}\text { CSR increases business relations and } \\
\text { new business opportunity } \\
\text { contributing to SBP }\end{array}$ & 0.888 & 0.986 & \\
\hline C41_B_G & $\begin{array}{l}\text { CSR allows for organisations to } \\
\text { receive recognition by international } \\
\text { credit organisations, } \\
\text { contributing to SBP }\end{array}$ & 0.862 & 0.987 & \\
\hline C41_B_H & $\begin{array}{l}\text { CSR improves the organisation's } \\
\text { competitiveness ultimately allowing } \\
\text { better turnover which } \\
\text { contributes to SBP }\end{array}$ & 0.857 & 0.987 & \\
\hline C41_B_I & $\begin{array}{l}\text { CSR reduces regulatory oversight } \\
\text { which contributes to SBP }\end{array}$ & 0.834 & 0.987 & \\
\hline C41_B_J & $\begin{array}{l}\text { CSR improves the business trust and } \\
\text { understanding between the business } \\
\text { and its customers contributing to SBP }\end{array}$ & 0.903 & 0.986 & \\
\hline C41_B_K & $\begin{array}{l}\text { CSR improves partnership } \\
\text { opportunities with transitional } \\
\text { organisations, contributing to SBP }\end{array}$ & 0.899 & 0.986 & \\
\hline C41_B_L & $\begin{array}{l}\text { CSR improves the organisation's } \\
\text { influence in the industry and market } \\
\text { share contributing to SBP }\end{array}$ & 0.856 & 0.987 & \\
\hline C41_B_M & $\begin{array}{l}\text { CSR increases the appeal to investors } \\
\text { and financial analysts } \\
\text { contributing to SBP }\end{array}$ & 0.832 & 0.987 & \\
\hline C41_B_N & $\begin{array}{l}\text { CSR allows the organisation to access } \\
\text { funding opportunities } \\
\text { contributing to SBP }\end{array}$ & 0.828 & 0.987 & \\
\hline C41_B_O & $\begin{array}{l}\text { CSR improves client retention that } \\
\text { contributes to SBP }\end{array}$ & 0.896 & 0.986 & \\
\hline
\end{tabular}

\section{References}

1. Van Scheers, L. SMEs marketing skills challenges in South Africa. Afr. J. Bus. Manag. 2011, 5, 5048-5056.

2. Vallie, Z. 2 Common Reasons Why Your Business May Be Failing. 2018. Available online: https://www.iol.co.za/businessreport/economy (accessed on 1 March 2019).

3. Ramukumba, T. Overcoming SMEs Challenges Through Critical Success Factors: A Case of SMEs in the Western Cape Province, South Africa. Econ. Bus. Rev. 2014, 16, 19-38. [CrossRef] 
4. Mofokeng, T.S. Assessment of the Causes of Failure among Small and Medium Sized Construction Companies in the Free State Province; University of Johannesburg: Johannesburg, South Africa, 2012.

5. Eke, C.; Aigbavboa, C.; Thwala, W.D. An Exploratory Study of the Causes of Failure in Construction Small Businesses: A Case of the Johannesburg Construction Industry; University of Johannesburg: Johannesburg, South Africa, 2015.

6. Aigbavboa, C.; Oke, A.; Kakanyo, F. Failure of Small and Medium Contracting Firms in Gauteng Province, South Africa. In Proceedings of the International Conference on Infrastructure Development and Investment Strategies for Africa, Livingstone, Zambia, 31 August-2 September 2016; pp. 344-351.

7. Aigbavboa, C.O.; Thwala, W.D. Challenges Facing Black Owned Small and Medium Construction Companies: A Case Study of Nelspruit-Mbombela Municipality, South Africa. J. Econ. Behav. Stud. 2014, 6, 771-778.

8. Bushe, B. The causes and impact of business failure among small to micro and medium enterprises in South Africa. Afr. Public Serv. Deliv. Perform. Rev. 2019, 7, 1-26. [CrossRef]

9. Ruf, B.M.; Muralidhar, K.; Brown, M.R.; Janney, J.J.; Paul, K. An empirical investigation of the relationship between change in corporate social performance and financial performance: A stakeholder theory perspective. J. Bus. Ethics 2001, 32, 143-156. [CrossRef]

10. Waddock, S.A.; Graves, S.B. The Corporate Social Performance-Financial Performance Link. Strateg. Manag. J. 1997, 18, 303-319. [CrossRef]

11. Turyakira, P.; Venter, E.; Smith, E. Corporate social responsibility for SMEs: A proposed hypothesised model. Afr. J. Bus. Ethics 2012, 6, 106-118. [CrossRef]

12. Choongo, P. A Longitudinal Study of the Impact of Corporate Social Responsibility on Firm Performance in SMEs in Zambia. Sustainability 2017, 9, 1300. [CrossRef]

13. Turyakira, P.K. Small and medium-sized enterprises (SMEs) engagement in corporate social responsibility (CSR) in developing countries: Literature review. Afr. J. Bus. Manag. 2017, 11, 464-469.

14. Jamali, D.; Lund-Thomsen, P.; Jeppese, S. SMEs and CSR in Developing Countries. Bus. Soc. 2017, 56, 11-22. [CrossRef]

15. Turyakira, P.; Venter, E.; Smith, E. The Impact of Corporate Social Responsibility Factors on the Competitiveness of Small and Medium-Sized Enterprises. SAJEMS 2014, 17, 157-172. [CrossRef]

16. Dahlsrud, A. How Corporate Social Responsibility is Defined: An Analysis of 37 Definitions. Corp. Soc. Responsib. Environ. Manag. 2008, 15, 1-13. [CrossRef]

17. Mandl, I.; Dorr, A. CSR and Competitiveness. European SMEs' Good Practice. In Consolidated European Report; Austrian Institute for SME Research: Vienna, Austria, 2007.

18. Commission of the European Communities. Promoting a European Framework for Corporate Social Responsibilities; 366 Final; COM: Brussels, Belgium, 2001.

19. Mersham, G.M.; Skinner, C. South Africa's bold and unique experiment in CSR practice. Soc. Bus. Rev. 2016, 11, 110-129. [CrossRef]

20. Fredericksz, L. The Corporate Social Responsibility Strategies and Practices of South African Organisations; Unpublished Masters Research Report; University of the Witwatersrand: Johannesburg, South Africa, 2015.

21. Ramasobana, A.M.; Fatoki, O. An Investigation into the Business Social Responsibility of Micro Enterprises in South Africa. Mediterr. J. Soc. Sci. 2014, 5, 283-289. [CrossRef]

22. Chiloane-Tsoka, E.; Rasivetshele, A.M. Corporate social responsibility a toolkit for SMEs efficiency in Tshwane. S. Afr. Probl. Perspect. Manag. 2014, 12, 276-282.

23. Goldengate Consulting. Corporate Social Responsibility Course Handbook; FASSET: Randburg, South Africa, 2012.

24. Fig, D. Manufacturing amnesia-Corporate social responsibility in South Africa. Int. Aff. 2005, 81, 599-617. [CrossRef]

25. Xia, B.; Olanipekun, A.; Chen, Q.; Xie, L.; Liu, Y. Conceptualising the state of the art of corporate social responsibility (CSR) in the construction industry and its nexus to sustainable development. J. Clean. Prod. 2018, 195, 340-353. [CrossRef]

26. Zhang, Q.; Oo, B.L.; Lim, B.T.H. Drivers, motivations, and barriers to the implementation of corporate social responsibility practices by construction enterprises: A review. J. Clean. Prod. 2019, 210, 563-584. [CrossRef]

27. Othman, A.A.E.; Mia, B. Corporate social responsibility for solving the housing problem for the poor in South Africa. J. Eng. Des. Technol. 2008, 6, 237-257. [CrossRef]

28. Othman, A.; Abdellatif, M. Partnership for integrating the corporate social responsibility of project stakeholders towards affordable housing development A South African perspective. J. Eng. Des. Technol. 2011, 9, 273-295.

29. Ladzani, W.; Seeletse, S. The status of business social responsibility among SMMEs in the built environment of Gauteng Province, South Africa. Acta Structilia 2010, 17, 29-52.

30. Ladzani, M.W.; Seeletse, S.M. Business social responsibility: How are SMEs doing in Gauteng, South Africa? Soc. Responsib. J. 2012, 8, 87-99. [CrossRef]

31. Mokwena, J.; Mashwama, N.X.; Thwala, D.; Aigbavboa, C.; Hamma-Adama, M. The Current State of Corporate Social Responsibility Practices of Firms Operating in Construction Industry. In Proceedings of the Emerging Technologies and Sustainability Principles in Structural Engineering and Construction, ISEC, Christchurch, New Zealand, 30 November-3 December 2020; Askarinejad, H., Yazdani, S., Singh, A., Eds.; ISEC Press: Fargo, ND, USA, 2020.

32. Munhall, P.L. Perception. In The SAGE Encyclopedia of Qualitative Research Methods; Given, L.M., Ed.; SAGE Publications, Inc.: Thousand Oaks, CA, USA, 2008; pp. 1-3. 
33. Agyekum-Mensah, G.; Knight, A.; Coffey, C. 4Es and 4 Poles model of sustainability: Redefining sustainability in the built environment. Struct. Surv. 2012, 30, 426-442. [CrossRef]

34. Wilkinson, A.; Hill, M.; Gollan, P. The sustainability debate. Int. J. Oper. Prod. Manag. 2001, 21, 1492-1502. [CrossRef]

35. Bonn, I.; Fisher, J. Sustainability: The missing ingredient in strategy. J. Bus. Strategy 2011, 32, 5-14. [CrossRef]

36. Sustainable. Available online: https://www.lexico.com/en/definition/sustainability (accessed on 16 February 2019).

37. Defining: Business Performance. Available online: https://www.igi-global.com/dictionary/business-performance/3068 (accessed on 21 December 2021).

38. Smith, T.M.; Reece, J.S. The Relationship of Strategy, Fit, Productivity, and Business Performance in a Services Setting. J. Oper. Manag. 1999, 17, 145-161. [CrossRef]

39. Hove, G.; Banjo, A. Performance in the Construction Industry-A Conceptual and Theoretical Analysis. Open J. Bus. Manag. 2015, 3, 177-184. [CrossRef]

40. Bevan, E.A.M.; Yung, P. Implementation of corporate social responsibility in Australian construction SMEs. Eng. Constr. Archit. Manag. 2015, 22, 295-311. [CrossRef]

41. World Business Council for Sustainable Development. Corporate Social Responsibility: Meeting Changing Expectations; World Business Council for Sustainable Development: Geneva, Switzerland, 1999.

42. Khoury, G.; Rostami, J.; Turnbull, J.P. Corporate Social Responsibility: Turning Worlds into Action; Conference Board of Canada: Ottawa, ON, Canada, 1999.

43. Business for Social Responsibility. Introduction to Corporate Social Responsibility. 2000. Available online: http://www.khbo.be/ $\sim\{\}$ lodew/Cursussen/4eingenieurCL/The\%20Global\%20Business\%20Resonsibility\%20Resource\%20Center.doc (accessed on 15 April 2019).

44. International Business Leaders Forum (IBLF). IBLF Members. 2003. Available online: http://www.iblf.org/csr/csrwebassist.nsf/ content/gi.html (accessed on 15 April 2019).

45. The Corporate Social Responsibility: An Opportunity for SMEs. Available online: http:/ /www.unglobalcompact.org/http://www. unece.org/indust/sme/ResponsibleEntrepreneurship (accessed on 15 April 2019).

46. Hou, T.C. The relationship between corporate social responsibility and sustainable financial performance: Firm-level evidence from Taiwan. Corp. Soc. Responsib. Environ. Manag. 2018, 26, 19-28. [CrossRef]

47. Why Social Responsibility Matters to Businesses. Available online: https://www.investopedia.com/ask/answers/041015/whysocial-responsibility-important-business.asp (accessed on 12 October 2021).

48. Yang, M.; Bento, P.; Akbar, A. Does CSR Influence Firm Performance Indicators? Evidence from Chinese Pharmaceutical Enterprises. Sustainability 2019, 11, 5656. [CrossRef]

49. Roberts, C.; Rapson, D.; Shiers, D. Social responsibility: Key terms and their uses in property investment. Prop. Invest. Financ. 2007, 25, 388-400. [CrossRef]

50. Yam Lee Hong, S.; Ismail, M.; Soo Yin, T. Corporate social responsibility in Malaysia housing development the developer's perspective. Pac. Rim Prop. Res. J. 2008, 14, 177-198. [CrossRef]

51. Wu, C.; Fang, D.; Liao, P.; Xue, J.; Wang, T. Perception of corporate social responsibility: The case of Chinese international contractors. J. Clean. Prod. 2015, 107, 185-194. [CrossRef]

52. Duman, D.U.; Giritli, H.; McDermott, P. Corporate social responsibility in construction industry: A comparative study between UK and Turkey. Built Environ. Proj. Asset Manag. 2016, 6, 218-231.

53. Santos, M. CSR in SMEs: Strategies, practices, motivations and obstacles. Soc. Responsib. J. 2011, 7, 490-508. [CrossRef]

54. Gamah, J.D. Corporate Social Responsibility (CSR) Engagement in the Ghanaian Construction Industry; Kwame Nkrumah University of Science and Technology: Kumasi, Ghana, 2014.

55. Parameshwara; Raghurama, A. Corporate Social Responsibility and SMEs in India. Indian J. Res. 2013, 2, 22-25.

56. Manuere, F. Corporate Social Responsibility Practices in Small to Medium Enterprises in Zimbabwe. Unpublished Ph.D. Thesis, University of KwaZulu-Natal, KwaZulu-Natal, South Africa, 2016.

57. Windapo, A.O.; Olugboyega, O.; Odediran, S. Impacts of procurement strategies on construction SMEs' growth. J. Financ. Manag. Prop. Constr. 2020, 25, 423-446. [CrossRef]

58. Czaja, R.; Blair, J. Designing Surveys, a Guide to Decisions and Procedures, 2nd ed.; SAGE Publications, Inc.: Thousand Oaks, CA, USA, 2005.

59. Ankrah, N.I. An Investigation into the Impact of Culture on Construction Project Performance. Ph.D. Thesis, SEBE, University of Wolverhampton, Wolverhampton, UK, 2007.

60. Akadiri, P.O. Development of a Multi-Criteria Approach for the Selection of Sustainable Materials for Building Projects. Unpublished Ph.D. Thesis, University of Wolverhampton, Wolverhampton, UK, 2011.

61. Oyewobi, L.O. Modeling Performance Differentials in Large Construction Organisations in South Africa. Unpublished Ph.D. Thesis, University of Cape Town, Cape Town, South Africa, 2014.

62. Takim, R.; Akintoye, A.; Kelly, J. Analysis of measures of construction project success in Malaysia. In Proceedings of the 20th Annual ARCOM Conference, Edinburgh, UK, 1-3 September 2004; Khosrowshahi, F., Ed.; Heriot Watt University: Edinburgh, UK, 2004; pp. 1-11.

63. Maree, K.; Pietersen, J. Surveys and the Use of Questionnaires. In First Steps in Research; Maree, K., Ed.; Van Schaik: Pretoria, South Africa, 2007. 
64. Pallant, J. SPSS Survival Manual: A Step by Step Guide to Data Analysis Using IBM SPSS, 7th ed.; Routledge: New York, NY, USA, 2020; pp. 1-361.

65. Clarkson, M.B.E. A stakeholder framework for analysing and evaluating corporate social performance. Acad. Manag. Rev. 1995, 20, 92-117. [CrossRef]

66. Mitchell, R.K.; Agle, B.R.; Wood, D.J. Toward a theory of stakeholder identification and salience: Defining the principle of who and what really counts. Acad. Manag. Rev. 1997, 22, 853-887. [CrossRef]

67. Camilleri, M.A. Strategic attributions of corporate social responsibility and environmental management: The business case for doing well by doing good! Sustain. Dev. 2021, 1-14. [CrossRef] 